\title{
All Work and No Play Makes an Adult a Dull Learner
}

\author{
Kuan Chen Tsai \\ Faculty of Humanities and Social Science, City University of Macau \\ 81-121 Av. Xian Xing Hai, Golden Dragon Centre, 19 Andares, Macau \\ E-mail: tsaikuanchen@cityu.edu.mo
}

Received: December 7, 2014 Accepted: December 18, 2014 Published: January x, 2015

doi:10.5296/jet.v2i1.6979 URL: http://dx.doi.org/10.5296/jet.v2i1.6979

\begin{abstract}
In educational contexts, the attributes of play and fun should be taken into consideration program design and content delivery, as these attributes can stimulate better learning results. This article proposes that playing with ideas and maintaining a playful attitude while constructing knowledge should be encouraged in adult classrooms. We begin with a review of the necessity of play for adult learners from the perspective of psychology. Then, we examine the relationship among creativity, imagination, and play. Finally, we look at the concept of play as it exists in practice in the adult classroom, and discuss its implications for adult educators.
\end{abstract}

Keywords: Play, Adult learning, Adult education

\section{Introduction}

The characteristics of flexibility in creative people has been well documented in the personality literature (Barron \& Harrington, 1981). According to data from Csikszentmihaly's (1996) interviews with nearly 100 luminaries across varied fields, the salient traits of mature creatives include playfulness and naïvete, particularly. When it comes to coping with obstacles to their creative achievements. It is widely believed that a central element of creativity is flexible thinking (Feist, 1998; Meneely \& Portillo, 2005), which allows creative people to play with different ideas on the way to a better solution. In this sense, the concept of play seems to function as a mediating variable between an individual's emotion and his/her creative performance.

Rubenson and Runco (1992) propose a psychoeconomic theory of creativity and focus on the problem of loss of creativity in older adults. They explain that people over 50 have invested large amounts of time and resources in formulating their routines and personal paradigms, and thus become less flexible when facing new challenges, especially ones susceptible to creative solutions. This lack of flexible ideation might also contribute to rigid attitudes toward the potential benefits of creative solutions. Runco (2009) has also voiced a concern 
that older adults might protect their investments, i.e., tend to be unwilling to consider alternatives as frequently as they did when they were younger.

In educational contexts, the attributes of play and fun should be taken into consideration program design and content delivery, as these attributes can stimulate better learning results. Cognition and affect are both important to the learning process. If learning is enjoyable, the construction of knowledge can be more effective and lead to better results. Play could also motivate adult learners to seek intellectual challenges and to continue to do so, which is the true meaning of lifelong learning. It is believed that the major trait of adult learners is self-directed inquiry, which has thus become a boldfaced term in the lexicon of the adult educator (Merriam, Caffarella, \& Baumgartner, 2007). Dirkx (1998) recognizes the importance to transformative learning of imagination and fantasy, which help adult learners understand the world around them. Following this line of thought, play could serve as important impetus toward the development of fantasy and imagination. Thus, from the perspective of meaning-making processes, embedding play into adult-learning curricula may not only boosts the magnitude of self-directed inquiry, but also render the learning journey more colorful and rich.

Dansky (1999) defined play as an activity is playful to the extent that it is "intrinsically motivated and self-directed" (p. 393). Cecil et al. (1985) defined play as creative activity that can be "conceptualized as the medium which illustrates the presence of the curious, exploratory and creative states" (p. 205). Dansky and Silverman (1973) remarked that "play involves a relaxation of efforts to adapt to reality" (p. 38), proposition similar to Piaget's (1962): that most play is behavior characterized by a predominance of assimilation over accommodation.

This article proposes that playing with ideas and maintaining a playful attitude while constructing knowledge should be encouraged in adult classrooms. Because it can encourage adult learners to explore new possibilities, the idea of play becomes an important facilitator of the learning process as a whole. On the one hand, play is closely related to creativity and imagination; on the other, it is speculated that play can enhance learning outcomes. We begin with a review of the necessity of play for adult learners from the perspective of psychology. Then, we examine the relationship among creativity, imagination, and play. Finally, we look at the concept of play as it exists in practice in the adult classroom, and discuss its implications for adult educators.

\section{Why Do Adult Learners Need Play?}

Herrmann (1990) proposed the brain dominance model, which consists of four different modes of thinking: analytical, sequential, interpersonal, and imaginative. This represents a refinement of left brain-right brain research, which suggested that the left hemisphere of the human brain processes thought in a linear, logical, and verbal manner, whereas the right one is characterized by the use of intuition, imagination, and visual hints. The four brain quadrants depicted by the Herrmann Whole Brain Model are intended to allow individuals to understand their thinking styles and learning preferences. 
In the literature on learning styles, another influential model is Kolb's Learning Style (Kolb, 1984), which involves two levels: a four-stage cycle of leaning (concrete experience, reflective observation, abstract conceptualization, and active experimentation) and four separate learning styles (diverging, assimilating, converging, and accommodating). It is easier to interpret Kolb's learning styles via a two-by-two matrix, in which each learning cycle is seen as a combination of two preferred styles. The theory holds that a better fit between a given situation and a individual's learning-style preferences will optimize that person's learning outcomes.

Both of the models discussed above carry important implications for educators. From the perspective of learners' internal cognitive processes, everyone is unique and has unique needs vis-à-vis the development of the most appropriate learning opportunities. As such, educators should recognize the importance of designing and implementing activities that offer each learner a better chance of becoming personally engaged.

Ideally, activities and materials should be delivered in a manner that suits students' varying needs and abilities as modeled by Kolb (1984) and Herrmann (1990). In other words, the logical and sequential approach to processing information should not dominate the classroom; rather, alternative approaches rooted in intuition and imagination should also be introduced, to fit the learning preferences among students. As such, it is possible to argue for the legitimate position of play in adult classrooms in two ways. First, play is an important facilitator of the exercise of right-brain activities, which are less linear, less logical, and less reality-based, and indeed, can be said to require a more fantasy-oriented style of information. In certain circumstances, therefore, play could be the best strategy by which to materialize knowledge. The second argument in favor of play in the adult classroom is rooted in the close relationship between play and creativity. The development of creative thinking is beneficial for adults' learning, and especially so for lifelong learning (Goff, 1993; Su, 2009; van der Veen, 2006); to the extent that play helps adults to cultivate their preferences for creative and flexible thinking, it should improve their learning outcomes.

The American Psychological Association (1993) has proposed a framework for developing curricula that encourage learner-centered learning. Focusing on a holistic view of real-world learning contexts, it highlights four categories of factors that affect learners and learning: cognitive and metacognitive, motivational and affective, developmental and social, and individual-difference. It is seems that positive emotion could boost students' learning and reinforce the learning process. In terms of the effects of play in adult-learning contexts, positive emotions and flexible thinking are the expected results. Educators should seriously consider promoting motivation via strategies that enhance purposeful learning, and take individual differences into account, especially regarding learning performance. Assessment provides valuable information and feedback for the selection of instructional materials and designs, which in turn can be tuned to an optimal degree in terms of progress toward learning goals.

\section{Creativity and Play}

Many scholars believe that play is key to children's development of cognitive, affective, and physical behaviors (Johnson, Christie, \& Yawkey, 1999). The majority of play research has 
been concentrated in the early-childhood literature, perhaps because the concepts of play, imagination, and creativity are strongly associated with children's free exploration and discovery of the world around them (Feldhusen \& Hobson, 1972; Klinger, 1969; Singer \& Rummo, 1973). It seems hard to disagree with Lieberman's (1965) dictum, that "playfulness implies freedom, spontaneity, and joy; so does divergent thinking” (p. 223).

Piaget (1962) suggested several characteristics of play that differentiate it from work. First, play is an end in itself, whereas work and other non-ludic behavior involve an aim not contained in the activity as such. Second, play is spontaneous, not compulsory. Third, play is undertaken for pleasure, while serious activity is directed towards a useful result irrespective of its pleasurable character. Fourth, play is considered to be devoid of organized structure, in contrast to serious thought, which is always ordered. Fifth, play is free from conflicts, whereas serious activity has to grapple with conflicts that are inescapable. And lastly play begins when incentives not contained in the initial action are included, and additional incentives would be characteristic of all play (pp. 147-150).

This is not to suggest, however, that all play is alike. Johnson et al. (1999) define games with rules, educational toys, and book-reading as cognitive play, while arts and crafts, microworlds and narratives, and musical expression are creative play (pp. 85-87); Piaget (1962) distinguished "symbolic play" from "practice play," noting that the former is to use objects to represent other objects as play, while the latter "as representational intelligence is to sensory-motor intelligence" (p. 163). Saracho (1992) argued that fantasy-play children's make-believe activity - is "associated with their concentration on and enjoyment of play situations" (p. 37). And, Russ and Kaugars (2000) state that "pretend play is play that involves the use of fantasy and symbolism" (p. 211). Despite these definitional and typological differences, however, all kinds of play, in essence, reflect the wellsprings of the creative imagination, fun and freedom; and that is why all children and even adults need play time to create a sandbox for trial and error.

Russ and her colleagues (Moore \& Russ, 2008; Pearson, Russ, \& Spannagel, 2008; Russ, 1993, 1998, 2003a; Russ \& Grossman-Mckee, 1990) assert that the main reason for the tight link between play and creativity is that play fosters the development of cognitive and affective processes that are required for creative performance. In the dimension of cognition, play behaviors stimulate processes that involve fluency, as well as divergent thinking: the sine qua non of creative thinking. In terms of affect, play stimulates affective pleasure in the face of challenges and in problem solving, and this becomes an important motivator for creative achievement. Affect itself has also been found to facilitate divergent thinking by reinforcing its magnitude. More specifically, as Russ (2003b) puts it,

in the affective realm, affective states (positive and negative), affective ideation and primary process thinking, extrinsic and intrinsic motivation, conflict resolution, and sublimation are a few of the affective processes that have been identified as important in the creative process (p. 143).

Russ (1993) follows the proposed cognitive-affective model of creativity that attempts to bridge primary and secondary thought processes, which are derived from Freud's proposition, 
that imagination, intuition, and emotion are located in the primary process of thinking, and logic, rules, and cognition are seated in the secondary process.

\section{The Practice of Play in Adult Learning}

The American Creativity Association's website provides a handful of exercises that promote creativity. The "Games" section in particular recommends several activities for educators (http://www.amcreativityassoc.org/page-1421207). These can be seen as useful play activities for adult learners. VanGundy (2005) likewise provides several game-like activities for the teaching of creativity, which could also be treated as play activities under the definitions provided in the previous section.

A number of studies have revealed that mind-mapping is effective in enhancing students' thinking skills and creativity (Keles, 2012; Wang, Lee, Chu, 2010; Zampetakis, Tsironis, \& Moustakis, 2006). It was developed by T. Buzan (1974) as a learning tool for maximizing brain potential in radiant thinking. Its primary feature is the connection of concepts with one another by utilizing images, characters, numbers, rhythm, colors, lines, and symbols. It aims to provide a free imaginary space in which to visualize associated thoughts, and then to integrate this information to form a map for the brain (T. Buzan \& B. Buzan, 1996). In short, mind-mapping is a useful and handy tool that allows adult learners to construct divergent thinking in the brain via pictorializing key concepts.

Although the majority of play literature focuses on pre-school children, play activities discussed in this literature (and commonly found in the classroom) such as collage, clay modeling and other art-making activities, building blocks, and treasure hunts could to some extent be transformed into activities that fit adult-learning contexts. The key to doing so rests with adult educators, who would need to take the lead in designing context appropriate activities that deliberately employ such techniques. A certain level of physical exercise that could trigger playful moods would be welcome in adult learning: in fact, somatic and embodied learning are seen in the adult-learning literature as powerful ways of knowing that engage the body as a site of learning (Merriam et al., 2007). As Freiler (2008, p.45) notes, "learning occurs in social contexts and bodies, not just in minds." A play activity, if designed to encourage direct engagement in individual bodily experience, could help adult learners to broaden their perspectives, and therefore their learning experience.

Several possible practices flow from the preceding discussion. First, play activity is especially suitable for collaborative learning via teamwork. Educators should design play activities that require each team member to engage in the task. Second, an effective educator should build a positive, safe, and playful learning environment and encourage adult learners to experiment in and with their learning processes. In such an environment, learners have more freedom to express themselves than they are given in traditional classroom settings. However, a playful environment does not absolve instructors of their responsibility to uphold the quality of learning, by providing sufficient support, direction, and guidelines. Finally, the design of learning should be authentic, i.e., attempt to echo real-life experiences rather than abstract instructional sequences. As a group, adult learners tend to be concerned with the relationship between what they are learning and how to apply it in their day-to-day life and 
work. As such, when designing play activities, educators should always consider this linkage to adults' experiences. Case-based play that is anchored in real-world events and issues is more likely to provide them with meaningful and authentic knowledge.

\section{Conclusions}

Understanding the nature and potential significance of play in the adult learning process can provide educators with a rationale for selecting appropriate educational methods, which in turn delimits adult learning. As Anderson (1994) wrote, "play is a safe harbor for the soul, because it is a separate reality in which meaning is inverted" (p. 82); thus, adult educators should reconsider the benefits of play for adult learning, which include cognitive, affective, and physical ways of constructing knowledge. Although research on play has thus far mainly been confined to studies of children, it is believed that the extension of this concept to older people could facilitate their creative performance, which in turn could optimize their learning success.

\section{References}

American Psychology Association. (1997). Learner-Centered psychological principles: A framework for school reform \& redesign. Washington, DC: Center for Psychology in Schools and Education.

Anderson, J. V. (1994). Creativity and play: A systematic approach to managing innovation. Business Horizons, 37(2), 80-85.

Barron, F., \& Harrington, D. M. (1981). Creativity, intelligence, and personality. Annual Review of Psychology, 32(1), 439-476.

Buzan, T. (1974). Use your head. London: BBC Books.

Buzan, T., \& Buzan, B. (1996). The Mind Map Book. London: BBC Books.

Cecil, L. M., Gray, M. M., Thornburg, K. R., \& Ispa, J. (1985). Curiosity-exploration-play-creativity: The early childhood mosaic. Early Child Development and Care, 19(3), 199-217.

Csikszentmihalyi, M. (1996). Creativity: Flow and the psychology of discovery and invention. New York, NY: HarperCollins.

Dansky, J. L. (1999). Play. In M. A. Runco \& S. R. Pritzker (Eds.), Encyclopedia of creativity (pp. 393-408). San Diego, CA: Academic Press.

Dansky, J. L., \& Silverman, I. W. (1973). Effects of play on associative fluency in preschool-aged children. Developmental Psychology, 9(1), 38-43.

Dirkx, J. M. (1998). Transformative learning theory in the practice of adult education: An overview. PAACE Journal of Lifelong Learning, 7(1), 1-14.

Feldhusen, J. F., \& Hobson, S. K. (1972). Freedom and play: Catalysts for creativity. The Elementary School Journal, 73(3), 148-155.

Feist, G. J. (1998). A meta-analysis of personality in scientific and artistic creativity. 
Personality and Social Psychology Review, 2(4), 290-309.

Freiler, T. J. (2008). Learning through the body. New Directions for Adult and Counting Education, 119, 37-47.

Goff, K. (1993). Creativity and life satisfaction of older adults. Educational Gerontology, 19(3), 241-250.

Herrmann, N. (1990). The creative brain. Lake Lure, NC: Brain Books.

Johnson, J. E., Christie, J. F., \& Yawkey, T. D. (1999). Play and early childhood development. New York, NY: Addison Wesley Longman.

Keles, O. (2012). Elementary teachers' views on mind mapping. International Journal of Education, 4(1), 93-100.

Klinger, E. (1969). Development of imaginative behavior: Implications of play for a theory of fantasy. Psychological Bulletin, 72(4), 277-298.

Kolb, D. A. (1984). Experiential Learning experience as a source of learning and development. Englewood Cliffs, NJ: Prentice Hall.

Lieberman, J. N. (1965). Playfulness and divergent thinking: An investigation of their relationship at the kindergarten level. Journal of Genetic Psychology, 107(1), 219-224.

Meneely, J., \& Portillo, M. (2005). The adaptable mind in design: Relating personality, cognitive style, and creative performance. Creativity Research Journal, 17(2-3), 155-166.

Merriam, S. B., Caffarella, R. S., \& Baumgartner, L. M. (2007). Learning in adulthood: A comprehensive guide. San Francisco, CA: Jossey-Bass.

Moore, M., \& Russ, S. W. (2008). Follow-up of a pretend play intervention: Effects on play, creativity, and emotional processes in children. Creativity Research Journal, 20(4), 427-436.

Pearson, B. L., Russ, S. W., \& Spannagel, S. (2008). Pretend play and positive psychology: Natural companions. Journal of Positive Psychology, 3(2), 110-119.

Piaget, J. (1962). Play, dreams and imagination in childhood. New York, NY: Basic Books.

Rubenson, D. L., \& Runco, M. A. (1992). The psychoeconomic approach to creativity. New Ideas in Psychology, 10(1), 131-147.

Runco, M. A. (2009). Simplifying theories of creativity and revisiting the criterion problem: A comment on Simonton's (2009) hierarchical model of domain-specific disposition, development, and achievement. Perspectives on Psychological Science, 4(5), 462-465.

Russ, S. W. (1993). Affect and creativity: The role of affect and play in the creative process. Hillsdale, NJ: Lawrence Erlbaum Associates.

Russ, S. W. (1998). Play, creativity, and adaptive functioning: Implications for play interventions. Journal of Clinical Child Psychology, 27(4), 469-480. 
Russ, S. W. (2003a). Play and creativity: Developmental issues. Scandinavian Journal of Educational Research, 47(3), 291-304.

Russ, S. W. (2003b). Creativity research: Whither thou goest. Creativity Research Journal, $15(2 / 3), 143-145$.

Russ, S. W., \& Grossman-Mckee, A. (1990). Affective expression in children's fantasy play, primary process thinking on rorschach, and divergent thinking. Journal of Personality Assessment, 54(3\&4), 756-771.

Russ, S. W., \& Kaugars, A. (2000). Emotion in children's play and creative problem solving. Creativity Research Journal, 13(2), 211-219.

Saracho, O. N. (1992). Preschool children's cognitive style and play: Implications for creativity. Creativity Research Journal, 5(1), 35-47.

Singer, D. V., \& Rummo, J. (1973). Ideational creativity and behavioral style in kindergarten age children. Developmental Psychology, 8(2), 154-161.

$\mathrm{Su}$, Y. H. (2009). Idea creation: The need to develop creativity in lifelong learning practices. International Journal of Lifelong Education, 28(6), 705-717.

van der Veen, R. (2006). Communication and creativity: Methodological shifts in adult education. International Journal of Lifelong Education, 25(3), 231-240.

VanGundy, A. (2005). 101 activities for teaching creativity and problem solving. San Francisco, CA: Pfeiffer.

Wang, W.-C., Lee, Y.-C., Chu, Y.-C. (2010). A brief review on developing creative thinking in young children by mind mapping. International Business Research, 3(3), 233-238.

Zampetakis, L. A., Tsironis, L., \& Moustakis, V. (2006). Creativity development in engineering education: The case of mind mapping. Journal of Management Development, 26(4), 370-380.

\section{Copyright Disclaimer}

Copyright reserved by the author(s).

This article is an open-access article distributed under the terms and conditions of the Creative Commons Attribution license (http://creativecommons.org/licenses/by/3.0/). 